\title{
Modelling the impact of landscape connectivity on catchment water balance and groundwater response
}

\author{
$\underline{\text { C. Beverly }}^{a}$ and M. Hocking ${ }^{b}$ \\ ${ }^{a}$ Department of Primary Industries, Rutherglen, Australia; \\ ${ }^{b}$ Hocking et al Pty Ltd, Melbourne, Australia \\ Email: craig.beverly@dpi.vic.gov.au
}

\begin{abstract}
Terrain analysis based on digital elevation models is being routinely used in hydrological modelling. However, landscape connectivity enabling the routing of flow and nutrients from upslope landscape units to adjacent downslope landscape units within a sub watershed is not commonly incorporated into catchment scale models. This paper describes a process of generating connected landscape units within sub watersheds based on a threshold area and evaluates the impact of landscape connectivity on catchment water balance and groundwater response.

Digital elevation models (DEMs) are commonly used for the automatic delineation of flow paths, sub watersheds and flow networks for hydrologic modelling. The capacity to define a flow path network describing how flow is routed to a drainage feature is fundamental to distributed hydrologic models. There is a variety of approaches for delineating flow networks using different flow direction algorithms, for example drainage to a single neighbouring cell or the partitioning of flow between multiple neighbouring cells. The resultant flow network underpins the watershed delineation based on upstream drainage area. This paper comments on each approach for representing the networks of rivers and streams and describes an approach using the watershed delineation to define landscape units using elevation intersects and flow paths connecting boundary nodes to drainage lines. This approach results in the generation of connected landscape units of variable size.
\end{abstract}

Catchment scale models typically adopt an aggregated or lumped spatial unit within which land use, soil and climate are proportionally assigned with limited spatial reference. This paper reports on the integration of connected topographic landscape units into a catchment modelling framework (Catchment Analysis Tool, CAT) with application to the Loddon catchment in central Victoria. Comparative results derived using the CAT under historical climate conditions show a $12 \%$ improvement in streamflow prediction compared to observed when accounting for landscape connectivity relative to the lumped approach. Comparative results also show significant variation in the recharge patterning and up to $30 \%$ variation in recharge rates depending on landscape position as estimated when using landscape connectivity relative to the lumped approach.

Incorporating landscape connectivity into a catchment modelling framework is shown to improve the predictive capacity of catchment models to estimate streamflow and groundwater recharge with associated improvement in water resource evaluation and flow and transport modelling

Keywords: Landscape connectivity, Catchment Analysis Tool (CAT), terrain analysis. 
Beverly and Hocking. Modelling the impact of landscape connectivity on catchment water balance...

\section{INTRODUCTION}

Terrain analysis using DEMs is being routinely applied in hydrological modelling. Elevation is a fundamental physical parameter defining soil-water gravitational potential energy (Moore et al., 2003) and is the primary influence of water movement throughout a landscape, as well as within drainage channels. DEMs are designed to represent the topology and so describe the shape of the land surface terrain, which can be analysed to define drainage area boundaries and predict water storage and transport on land (Moore et al., 1992).

Numerous toolkits and terrain models are available either through research groups or as incorporations into commercial software. ARC Hydro (Maidment, 2002) has been developed as a generic geographic data model available as an ESRI GIS module. Utilities available include drainage analysis, stream definition, watershed delineation and watershed analysis. The CRC for Catchment Hydrology (www.toolkit.net.au) and the CRC eWater have a suite of terrain models (Walker et al, 2003) including 2CSalt which generates depressionless sub-catchment delineation, the delineation of valley bottom flatness and partitioning of catchments into hill slope regions and alluvial zones adjacent to drainage lines. CLASS Spatial Analyst (Teng et al., 2004) is a GIS based tool with utility to calculate Topographic Wetness Index, Compound Topographic Index, lateral multiple flow paths, estimation of soil depth, soil material/horizon distribution and soil moisture capacity in different parts of the landscape. Tools available with no display capacity include TARDEM (http://www.crwr.utexas.edu/gis/gishydro99/uwrl/tardem.html) and Tarsier (Watson, 1999). The Height Above the Nearest Drainage (HAND) model normalizes topography according to the local relative heights along a drainage network and by so doing describes the soil gravitational potentials, or local draining potentials (Nobre et al., 2011). The majority of these models operate on raster spatial data and approximate flow direction using either the D8 or D $\infty$ (Tarboton, 1997) procedures. The D8 flow direction function constrains flow from a grid cell to only one of eight neighbouring grid cells with the steepest descent/downhill slope, whereas the $\mathrm{D} \infty$ approach is not constrained to a singe flow direction. Ha et al. (2009) considers computational fluid dynamic principles to describe flow pathways with accounting for particle momentum whereas Chua et al. (2009) describes a new adaptive algorithm for the calculation of flow lines and contributing upslope areas.

An increasing number of distributed physically based catchment models have been developed in parallel with and often utilising the generation of robust DEMs and terrain analysis tools, including: TOPOG (O'Loughlin 1986, Beverly 1992); SHE (Abbott et al., 1986); TAPES-C (Moore et al, 1986, Moore and Grayson 1991); SWAT (Neitsch et al., 2000); OBJTOP (Wang et al., 2005) and CAT (Beverly et al., 2005). These models can simulate surface hydrological processes reasonably well and are better suited than lumped conceptual models for the prediction of the hydrological impacts of future climate and land use changes (Nobre et al., 2011). However, distributed physically based models require additional spatial data sets and associated parameterisation of physical properties. Notwithstanding this, a consistent regionalisation method of representing catchment dynamics using a deterministic generalised model that accounts for topographic impacts on soil-water-plant interactions could be a valuable tool. An additional consideration is that most catchment-scale biophysical models adopt generic vegetation growth algorithms to represent the diverse range of farming systems that exist within a catchment. This is a limitation if the aim is to explore the tradeoff between, say, plantation management and rotational grazing on a multi-sward pasture enterprise as these systems requires very different characterization.

This paper applies the CAT catchment modeling framework which comprises a range of farming system models of varying complexity (to account for different land uses) with enhanced terrain data to describe soil depth and landscape connectivity. The aim of this study was to (1) develop a simple automated method for delineating catchments into connected landscape units and (2) to evaluate by application to a pilot catchment the proposed improvement in predictive capability of biophysical catchment models to estimate streamflow and groundwater responses by consideration of landscape connectivity. To meet this aim, this paper firstly describes a procedure for deriving connected landscape units from a DEM to be used within a biophysical catchment modeling framework. The paper concludes with an application of a catchment model to the Loddon catchment in northern Victoria and compares results derived with and without accounting for landscape connectivity. 
Beverly and Hocking. Modelling the impact of landscape connectivity on catchment water balance...

\section{DERIVING CONNECTED LANDSCAPE UNITS FROM A DEM}

\subsection{Overview}

The sequence of operations to generate spatially variable connected landscape units was based on a sequence of seven steps summarized as follows:

1. Create a depressionless DEM.

2. Create internal watersheds based on an area threshold.

3. Create a drainage network.

4. For those watersheds with terminating internal nodes, artificially extend the drainage line to the upslope catchment boundary.

5. For those watersheds dissected by a drainage line extending from a boundary to a distant boundary, partition the watershed into multiple zones.

6. Define new landscape units defined by zones within each watershed that contribute to drainage features within each watershed. Given that some watersheds may have originally had both terminating internal drainage lines connected to a major river segment that traversed the watershed, this process may results in multiple additional zones within the original watershed domain.

7. Intersect each landscape unit with elevation bands to create zones that topographically connect from up-slope regions to a down-slope drainage line.

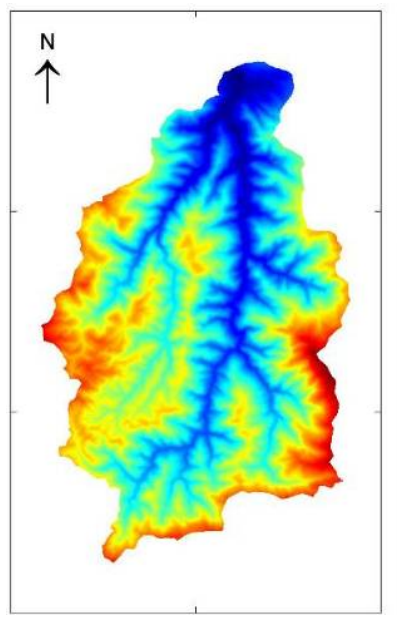

Figure 1: Original DEM (mAHD).

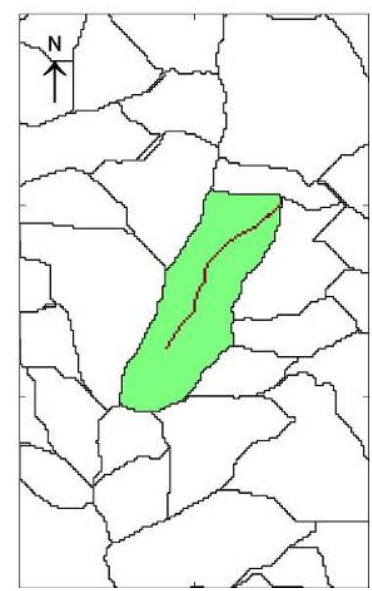

Figure 4: Outputs from step 4.

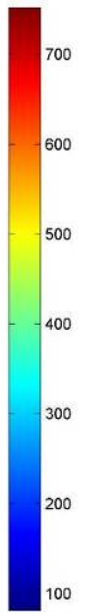

Figure 2: Outputs from step 2. Also shown is the zoomed region. (This is a subset of Figs. 1 and 2.)

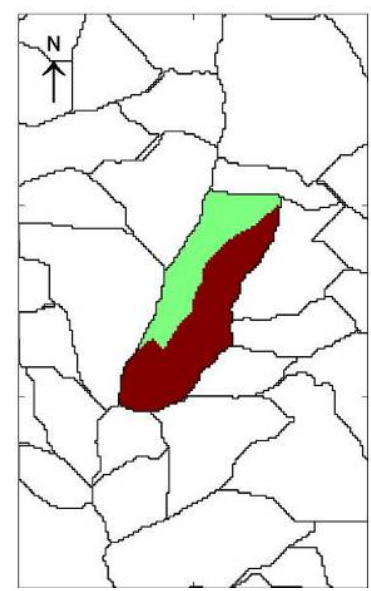

Figure 5: Outputs from step 6.

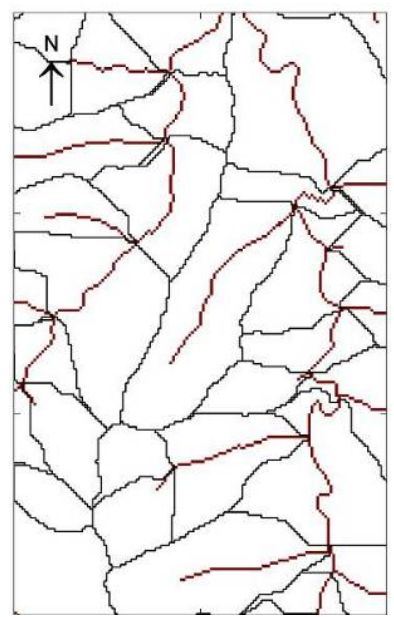

Figure 3: Outputs from step 3.

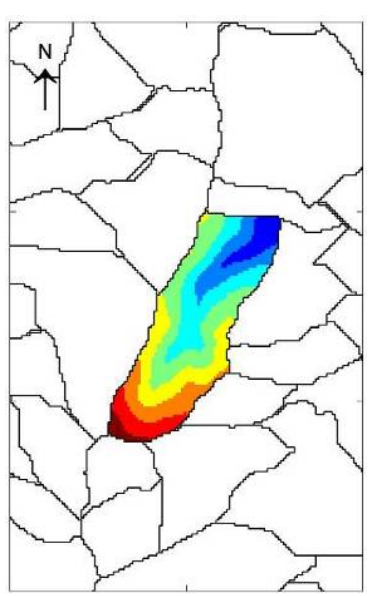

Figure 6: Outputs from step 7. 
Beverly and Hocking. Modelling the impact of landscape connectivity on catchment water balance...

The number of connected landscape units can be varied based on the elevation intervals and a maximum distance along a drainage line from which to further sub-divide zones.

\subsection{Soil depth estimation}

Soil depth was estimated based on delineating landform elements as described by McKenzie et al. (2003) and adapted by Murphy et al. (2005). The method predicts the depth of soil using two indices, namely the Topographic Wetness Index (TWI) (Wilson and Gallant, 2000) and the Multi-Resolution Valley Bottom Flatness Index (MrVBF) (Gallant and Dowling, 2003). These two topographic indices are combined to estimate the depth of the A horizon using a weighting function that has a bias towards TWI on the hill slope and MrVBF on the valley flats. The estimated thickness of the lower subsoil layers are based on the estimated thickness of the A horizon. This approach is founded on the assumption that soil formation and depth of soil is dependent on position in the landscape, parent material and slope. This approach has been applied to a number of catchments in NSW with soil depth predictions within observed limits (Murphy et al. 2005, Feikema, pers comm).

\section{CATCHMENT MODEL}

The modelling approach used the Catchment Analysis Tool (CAT) framework (Beverly et al., 2005; DPI, 2009) to assess the on-site and off-site impacts of various vegetation restoration strategies aimed at reducing catchment salt exports. This model uses a combination of a suite of farming system models linked within a catchment framework with allowance for landscape connectivity and connection to a distributed, multilayered groundwater model. The farm-scale models range in complexity from a simple crop factor approach to phenologically based crop, pasture and forest growth modules and account for position in the landscape (topography, soil type, aspect and slope), climate, land use and land management and simulate water balance, nutrient transport and production on a daily time step. This framework provided the user the option of simulating the phenological development of a crop using either a user-defined crop cover, a daily-heat unit accumulation approach or a vegetative cycling approach depending on data availability and user capability. A common water balance, erosion, nutrient, carbon and soil evaporation module is used by all the available crop-growth models. The CAT has also been developed to link with the fully distributed multi-layer groundwater model MODFLOW (McDonald and Harbaugh, 1988) to account for groundwater dynamics and provide a whole-of-catchment water balance whereby recharge estimates from the farming system models are explicitly incorporated into the groundwater model. The CAT model requires daily meteorological data including precipitation, maximum and minimum air temperature, solar radiation, evaporation and vapour pressure.

\section{THE LODDON CATCHMENT APPLICATION}

\subsection{Model application objectives}

The Loddon Catchment (Figure1) encompasses approximately 611,316 hectares with the main land uses being dryland grazing, production forestry and cropping. The significant variation in elevation from $105 \mathrm{~m}$ AHD in the north and $823 \mathrm{~m}$ AHD in the south cause variation in environments, such as mean annual rainfall varying from $410-1170 \mathrm{~mm}$. Further details of the hydrogeological conceptualisation and groundwater model calibration can be found in Beverly 2010 and Beverly 2008. Model calibration statistics of measure versus observed were found to be a scaled root mean square of $1.94 \%$ and mean sum of residuals of $7.43 \mathrm{~m}$.

As with the validation process, simulations were conducted from December 1993 to July 2005. To demonstrate the impact on predicted stream flow, recharge patterning and depth to watertable by consideration of landscape connectivity, two scenarios were considered, namely:

1. Current land use with infiltration excess, runoff and lateral flows directly connected to stream

2. Current land use with infiltration excess, runoff and lateral flows connected to down-slope units.

Simulated depth to water table, stream yield, and spatial recharge are compiled for each scenario. The second scenario requires a simulation solution tree to be developed ensuring that all up-slope cells are solved prior to solving down-slope units. This approach essentially cascades surface runoff and subsurface lateral flows from high points to lower points within the landscape. 
Beverly and Hocking. Modelling the impact of landscape connectivity on catchment water balance...

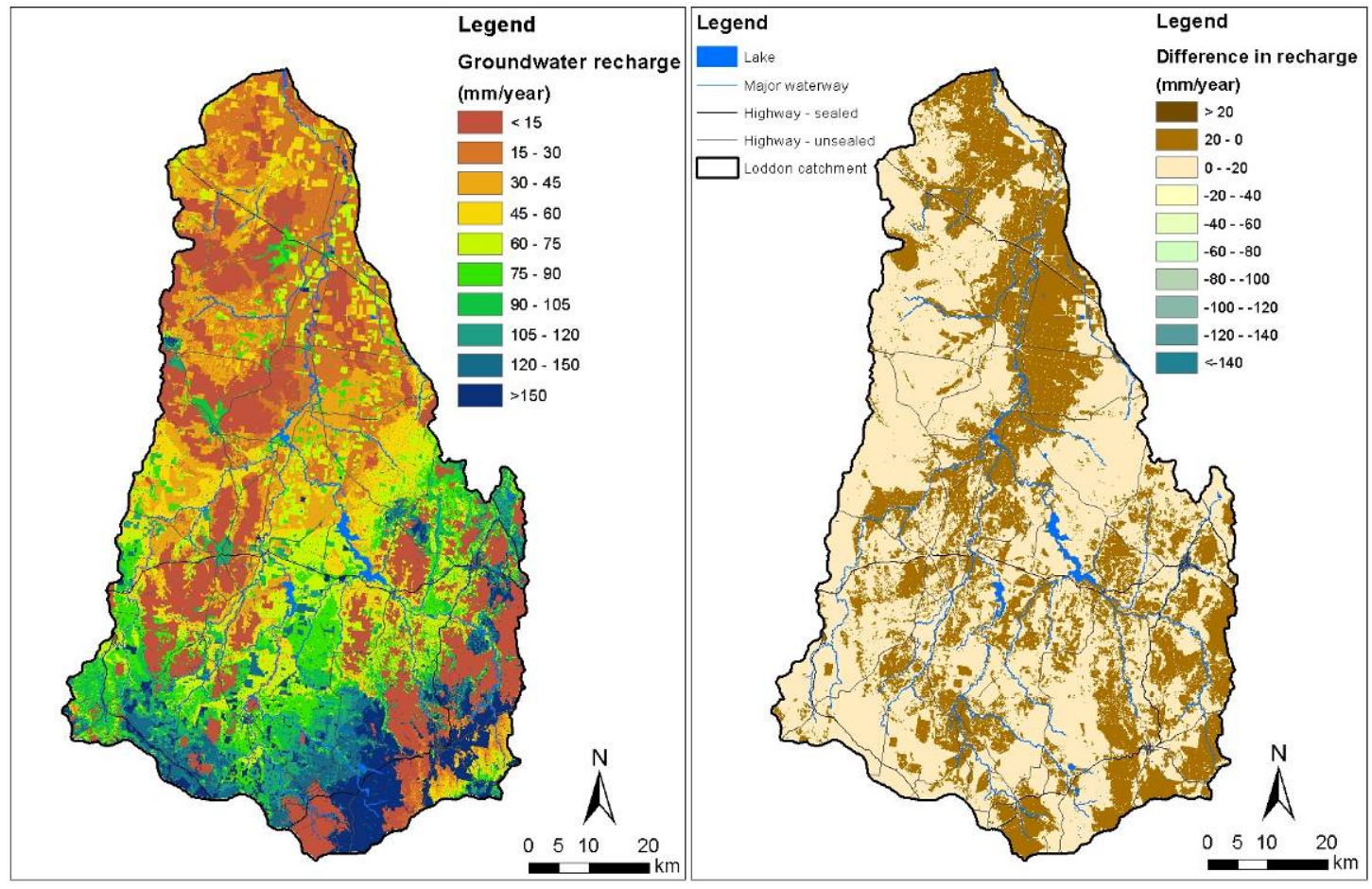

Figure 7: Spatial recharge patterning derived using the CAT assuming no landscape connectivity (left) and the difference when accounting for landscape connectivity (right). Positive values indicate regions of greater recharge when accounting for landscape connectivity as shown in the alluvial regions, whereas negative values implies a reduction in recharge as shown in the upland regions.

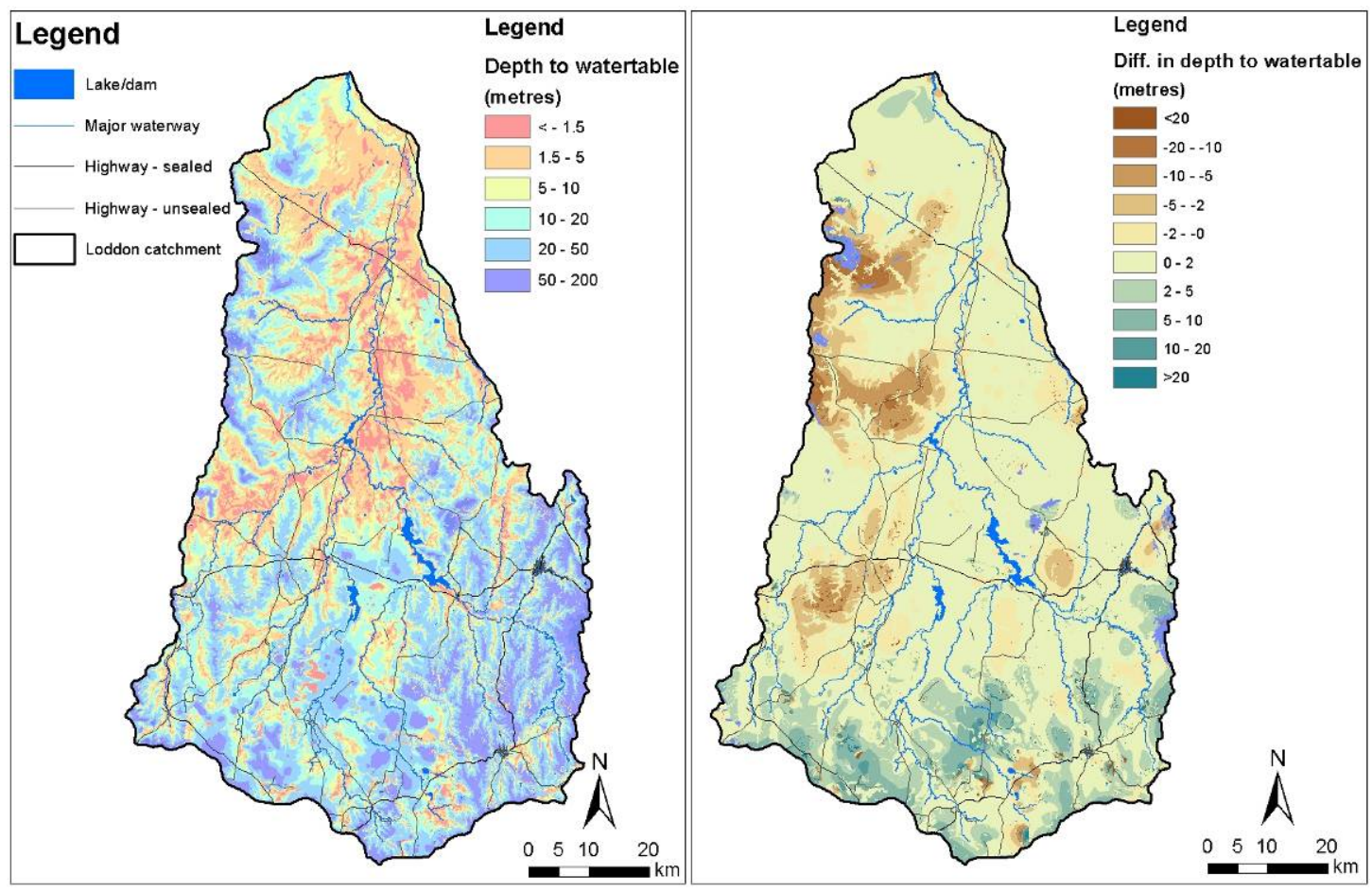

Figure 8: Long term equilibrium depth to watertable estimates derived assuming no landscape connectivity (left) and the difference when accounting for landscape connectivity (right). Positive values indicate regions of greater depth to watertable when accounting for landscape connectivity as shown in the upland regions, whereas negative values implies a reduction in depth to watertable as shown in the alluvial regions. 
Beverly and Hocking. Modelling the impact of landscape connectivity on catchment water balance...

\subsection{Calibration of the Loddon model}

The linked surface water/groundwater Bet Bet catchment model was calibrated based on matching streamflow, salt loads and groundwater hydrograph data for the period 1974-2000. Streamflow results were also compared to the Loddon REALM Model (SKM 2004). The mean annual results derived using the CAT for baseflow and streamflow were $17 \mathrm{~mm} / \mathrm{yr}$ and $55 \mathrm{~mm} / \mathrm{yr}$ respectively compared to REALM estimates of $13 \mathrm{~mm} / \mathrm{yr}$ and $57 \mathrm{~mm} / \mathrm{yr}$. A coefficient of determination of 0.71 was derived based on comparing monthly observed versus predicted streamflow with a Nash-Sutcliffe Index (NSI) (Nash and Sutcliffe, 1970) of 0.74.

A multi-layered distributed groundwater using MODFLOW has previously been developed (Beverly and Hocking, 2009) for the Bet Bet catchment and calibrated for the period 1974 to 2000 inclusive using groundwater bore hydrograph datasets and mapped discharged site information. This model was used in the current study to estimate the potentiometric surface and groundwater discharges under various land-use scenarios. Calibration of the catchment model was based on matching groundwater hydrograph responses from representative observation bores and streamflow from the three stream flow gauges on the Bet Bet Creek that are located within the pilot catchment. The calibrated groundwater model estimated an area of 16,200 ha to be subject to a high watertable less than $1.5 \mathrm{~m}$ from surface which was in agreement with the groundwater discharge based on aerial photographs of 15,500 ha.

\subsection{Scenario testing}

Comparative recharge and depth to watertable spatial maps derived with and without accounting for landscape connectivity are shown in Figures 7 and 8 respectively. The associated mean annual water balance components for the period 1957 to 2005 are summarized in Table 2. Also summarised in Table 2 are the long term depth to watertable extents derived using the spatial recharge estimates shown in Figure 7. Analysis of simulated monthly streamflow derived with allowance for landscape connectivity shows a $12 \%$ improvement when compared to measured data at the end-ofvalley catchment gauge relative to simulations derived with no landscape connectivity.

\section{DISCUSSION AND CONCLUSIONS}

Results show a significant redistribution of water in the upland regions of the catchment and more recharge in the valley bottoms and lower parts of the catchment when connected landscape units are considered. Comparative results derived using the CAT under historical climate conditions show a $12 \%$ improvement in streamflow prediction compared to observed when accounting for landscape connectivity relative to the lumped approach. Comparative results also show significant variation in the recharge patterning and up to $30 \%$ variation in recharge rates depending on landscape position as estimated when using landscape connectivity relative to the lumped approach.

Incorporating landscape connectivity into a catchment modelling framework is shown to improve the predictive capacity of catchment models to estimate streamflow and groundwater recharge with associated improvement in water resource evaluation and flow and transport modelling. Additionally, landscape connectivity recharge simulation has shown to result in generally shallower watertables in valley floors and a deeper watertable on hill tops.

\section{ACKNOWLEDGMENTS}

The authors acknowledge the support of DPI Victoria in funding this study. 
Beverly and Hocking. Modelling the impact of landscape connectivity on catchment water balance...

\section{REFERENCES}

Abbott, M.B., Bathurst, J.C., Cunge, J.A., O’Connell, P.E., and Rasmussen, J. (1986). An introduction to the European hydrological system - Systeme Hydrologique Europeen (SHE), Journal of Hydrology, 87,45-59.

Beverly C. and Hocking (2009) Predicting groundwater response times and catchment impacts to landuse change. $18^{\text {th }}$ World IMASC/MODSIM Congress, Cairns 2009. http://mssanz.org.au/modsim09.

Beverly, C, Hocking, M., Wilford, J. and Lawrie, K. (2008). Building more robust hydrological models underpinned by new regolith-landform information. 2nd International Salinity Conference, Adelaide, April 29-March 52008

Beverly, C., Bari, M., Christy, B., Hocking, M. and Smettem, K. (2005). Predicting salinity impacts from land use change: comparison between rapid assessment approaches and a detailed modelling framework. Australian Journal of Experimental Agriculture, 45, 1453-1469.

Beverly C.R. (1992), Background notes on the CSIRO Topog model. 1 Details of the numerical solution of the Richards equation in Topog_Yield, CSIRO Technical Memorandum, 92/12, pp 1-51.

DPI (2009). Models of the Catchment Analysis Tool (CAT1D Version 32), Ed. C. Beverly, Technical Reference Manual, Department of Primary Industries, ISBN: 978-1-74217-681-9, pp214

Gallant, J.C. and Dowling, T.I. (2003). A multi-resolution index of valley bottom flatness for mapping depositional areas, Water Resources Research, 39 (1), 1347.

Ha, J., Chua, J. and Eigenraam, M. (2009). Testing a particle approach to determine surface water flow over a terrain, $18^{\text {th }}$ World IMACS/MODSIM Congress, Cairns, Australia, 13-17 July, 2009, Conference CD.

Harbaugh, A. and McDonald, M. (1996), User's documentation for MODFLOW-96, an update to the U.S. Geol. Surv. modular finite difference groundwater flow model: U.S. Geol. Surv. Open-File 90-485, 56p.

McKenzie, N., Gallant, G. and Gregory, L. (2003). Estimating water storage capacity in soil at the catchment scale. Technical Report 03/3, CRC for Catchment Hydrology, Australia.

Maidment, D.R. (2002). Arc Hydro - GIS for Water Resources, D.R. Maidment (ed), ESRI Press, Redlands, California, 203pp.

Moore, I.D., Gessler, P.E., Nielsen, G.A. and Peterson, G.A. (1993). Soil attribute prediction using terrain analysis. Soil Science Society Of America Journal, 57, 443-452.

Moore, I.D., Grayson, R.B. and Ladson, A.R. (1992). Digital terrain modeling: a review of hydrological, geomorphological and biological application. Hydrological Processes, 5(1), 3-30.

Moore, I.D. and Grayson, R.B. (1991). Terrain-based catchment partitioning and runoff prediction using vector elevation data, Water Resources Research, 27(6), 1177-1191.

Murphy, B., Vaze, J., Teng, J., Tuteja, N.K., Gallant, J., Summerell, G., Young, J. and Wild, J. (2005). Modelling landscapes using terrain analysis to delineate landforms and predict soil depth - examples from catchments in NSW. In Zerger, A. and Argent, R.M. (eds) MODSIM 2005 International Congress on Modelling and Simulation. Modelling and Simulation Society of Australia and New Zealand, December 2005, pp. 1423 - 1429, ISBN: 0-9758400-2-9.

Nash, J.E. and Sutcliffe, J.V. (1970). River flow forecasting through conceptual models, 1. A discussion of principles. Journal of Hydrology, 10, 282-290.

Neitsch, S.L., Arnold, J.G., Kiniry, J.R. and Williams, J.R. (2001). Soil Water Assessment Tool Theoretical Documentation, Version 2000. (Grassland, Soil and Water Research Laboratory, Temple, Texas)

Nobre, A.D., Cuartas, L.A., Hodnett, M., Renno, C.D., Rodrigues, G., Silveira, A., Waterloo, M. and Saleska, S. (2011). Height Above the Nearest Drainage - a hydrologically relevant new terrain model. Journal of Hydrology, 404, 13-29.

O'Laughlin, E.M. (1986). Prediction of surface saturation zones in natural catchments by topographic analysis. Water Resources Research, 22(5), 794-804.

SKM (2004) Upper Loddon REALM model update. Sinclair Knight Merz, 100pp.

Tarboton, D.G. (1997). A new method for the determination of flow directions and contributing areas in grid digital elevation models, Water Resources Research, 33(2), 309-319.

Teng., J. Vaze, J. and Tuteja, N.K. (2004). CLASS Spatial Analysist. User's Manual. NSW Department of Infrastructure, Planning and Natural Resources, Australia and the Cooperative Research Centre for catchment Hydrology, Australia, ISBN 0734755163.

Walker, G.R., Gilfedder, M., Evans, W.R., Dyson, P. and Stauffacher, M. (2003). Groundwater flow systems framework - essential tools for planning salinity management, MDBC Publication 14/03, Murray-Darling Basin Commission, Canberra.

Wang, J., Endreny, T.A. and hassett, J.M. (2005). A flexible modeling package for topographically based watershed hydrology. Journal of Hydrology, 314, 78-91.

Watson, F. (1999). Tarsier On-line Help, Earth Systems Science and Policy, California State University.

Wilson, J.P. and Gallant, J.C. (2000). Secondary topographic attributes. In: Wilson, J.P. and gallant, J.C. (eds), Terrain Analysis: Principles and Applications, pp. 87-131, John Wiley and Sons, New York. 